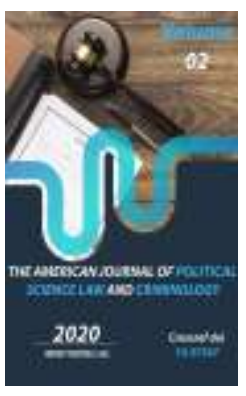

\title{
New Phase Of Reforms In The Sphere Of Judiciary In Uzbekistan
}

\author{
Saidov Bakhrom Anvarovich \\ Associate Professor, Doctor Of Science In Law, Secretary Of The Academic Council Of The \\ Academy Of The Ministry Of Internal Affairs, Uzbekistan
}

Journal Website: http://usajournalshub.c om/index,php/tajpslc

Copyright: Original content from this work may be used under the terms of the creative commons attributes 4.0 licence.

\section{ABSTRACT}

This article analyzes the phases of reforms in the sphere of judiciary in periodical order, the significance of the resolutions and decrees adopted at the new stage of reform and the initial results are highlighted.

\section{KEYWORDS}

Crime, criminal procedure, law of defense, rights and freedoms, legitimate interests, human rights, international law norms.

\section{INTRODUCTION}

Obtaining the citizens ' complete confidence by ensuring the rights and freedoms of the participants in the criminal proceedings is considered to be one of the prior task, as well as prevention, prompt and full disclosure of crimes, non-prosecution of innocent people, ensuring equality of the sides at all stages of criminal proceedings, reasonable use of coercive procedural measures, terminating discriminatory treatment, torture, cruel, inhuman or degrading behavior and the practice of imposing penalties in judicial proceedings, releasing person as a result of his/her sincere repentance and active participation in the detection of the crime, by fully compensating the property damage caused to the victims are of great importance in the world.

The following tasks are of paramount importance namely; finding scientific, 
theoretical and practical solutions to the criminal-procedural problems which can be met in the national legislation and law enforcement practices that protect the rights of participants in the proceedings, improving legal mechanisms for compensation and assistance to victims of crime, ensuring the transparency and openness of judicial proceedings, strengthening the role of the institution of public participation in the criminal proceedings, further expanding the scope of private prosecution, reconciliation and "Habeas corpus" institutions around the world, taking all necessary measures to restore the violated rights of the individual, improving the affair of preliminary investigation and investigative organs to ensure individual rights, freedoms and legitimate interests, strengthening control, liberalization of procedural procedures in criminal cases - are becoming gradually topical.

Obviously, any democratic state formally defines the rights and freedoms of its citizens in the constitution and laws, and provides and guarantees its economical mechanism. In fact, the most important aspect of the characteristics of the democratic regime is also reflected in this principle.

More than 20 codes and 500 laws on the protection of human rights has been adopted by the parliament of our country in the independence years. Along with the adoption and implementation of these laws, the current legislation has been gradually improved based on the analysis of existing problems in this field, as well as the study of the experience of developed countries.

The judicial reforms can be divided into the following phases in order to ensure the constitutional rights and freedoms of the individual:
The first phase, covers 1991-2000 years, the drafts of the criminal and criminal procedural codes were prepared and adopted, as well as measures were taken to eliminate the initial problems that arose in the process of their implementation. At this stage, relevant laws have been enacted to transform the judiciary system from a punitive organ into an independent state institution that serves to reliably protect human rights and freedoms.

Institutions for the protection of the rights, freedoms and legally-protected interests of citizens in the criminal proceedings have been established. Legal mechanisms have been created to enable equality of prosecution and defense during the trial.

The second phase, covers 2001-2010 years, was the period of active democratic renewal and modernization of the country, consistent reform of the legislative and judicial system. Capital punishment was abolished in the country and replaced by life imprisonment and long-term imprisonment from January 1, 2008. The right to sanction a person's detention was transferred from the prosecutor's office to the courts from January 1, 2008. The activity of the prosecutor's office has been reformed, that is, it has become the organ that ensures the rigid implementation of laws, the consistent development of democratic reforms in our country, the reliable protection of human rights and freedoms, rather than the punitive means. At the pre-trial stage, amendments and additions were modified to the criminal and criminal-procedural legislation in order to strengthen judicial control and improve the institution of advocacy.

The third phase, covers 2011-2016 years, focused on strengthening the independence of the judiciary and raising the judicial process to the qualitatively new level. Courts were excluded from the scope of subjects entitled to 
initiate criminal proceedings. Consideration of petitions for dismissal of the accused, placement of the person in the medical institution was transferred to the jurisdiction of the courts. This allowed strengthening judicial control and further expanding the use of the institution of habeas corpus in the criminal proceedings.

The obligation to read the indictment rested solely with the prosecutor, and the power to initiate criminal proceedings was removed from the jurisdiction of the courts. This amendment served to ensure the independence, impartiality and transparency of the judiciary, and to strengthen the principle of adversarial proceedings.

The fourth phase, covers the period from September 2016, when the President of the Republic of Uzbekistan Shavkat Mirziyoyev took office as the head of state up to this day.

The adoption of the Strategy of Actions for the five priority areas of development of the Republic of Uzbekistan for 2017-2021 has become an important legal basis for improving judicial reform, as in all spheres of society. The document aims to strengthen the guarantees of real independence of the judiciary and reliable protection of the rights and freedoms of citizens, increase the efficiency of administrative, criminal, civil and economic legislation, the fight against crime and crime prevention, aimed at ensuring the rule of law and further reform of the judiciary, as well as the issues of full implementation of the principle of adversarial proceedings, radical improvement of the quality of legal assistance and services during the trial were identified.

In order to provide the fulfillment of these tasks, the scope of the Habeas Corpus institution has been expanded; judicial control over the investigation has been strengthened; the powers of the lawyer have been expanded at all stages of the investigation and trial; criminal and criminal-procedural legislation to ensure reliable protection of the rights and freedoms of citizens in the activities of the judiciary, law enforcement and regulatory agencies have been improved.

The drastic steps taken to ensure that the courts operate independently of the prosecutor's office are showing its results, as can be seen in the case of acquitted persons over the past three years. In the past 3 years, 1,989 people were acquitted, and in 2019, 859 people were acquitted. Also, in 2019, 3 thousand and 81 individuals were released from the courtroom, 2,623 people were acquitted and altered [1].

It is quite straightforward that justification is a very important concept when one imagines the fate of people who have lost their years, youth, health, and lives before justifying their name, honor, and reputation in life.

This new stage of the ongoing reforms began to accept, in the judicial system of the country is associated with the Decree of the President of the Republic of Uzbekistan, Shavkat Mirziyoyev dated on October 21, 2016 No PR4850 [2]. This decree identified the main priorities of state policy in the field of further reform of the judicial system, ensuring true independence of the judiciary, reliable protection of the rights and freedoms of citizens, as well as increasing access to justice.

The abolition of the procedure for remanding criminal cases for further investigation by the courts allows the courts and investigative organs to determine the truth and other circumstances that are important for the proper resolution of the case, as well as increase their responsibility to make lawful, reasoned and fair decisions. 
Previously, the analysis of cases returned for additional investigation showed that in most cases, they were incomplete and one-sided, the crime was incorrectly qualified, the defendant's rights to defense was violated, and his identity was not sufficiently identified [3]. Therefore, the abolition of this institution, which does not justify itself and violates the constitutional rights and freedoms of the individual in the criminal proceedings, is fully consistent with the democratic reforms being carried out in the system.

General investigation department of the ministry of internal affairs of the Republic of Uzbekistan transferred to the Investigation department under the ministry of internal affairs of the Republic of Uzbekistan in accordance with the Decree of the President of the Republic of Uzbekistan dated on April 10, 2017 No PR-5005 "On measures to radically improve the efficiency of the activity of the internal affairs organs, strengthen their responsibility to maintain public order, reliable protection of citizens' rights, freedoms and legitimate interests".

Decree of the President of the Republic of Uzbekistan dated on April 18, 2017 No PD-2898 "On measures to radically improve the activities of internal affairs organs in the sphere of criminal investigation", plays a key role to prevent humiliation of human dignity and legitimate interests, to collect evidence during the investigation and adherence to the requirements of evidence acceptability in strengthening, eliminating the use of illicit methods such as torture, psychological and physical coercion, and other forms of cruel, inhuman, or degrading treatment against participants in the criminal proceedings.

In particular, special rooms equipped with shorthand, video surveillance, as well as audio and video recording of investigative actions were set up in the internal affairs organs. The resolution also prohibits the use of evidence of witnesses, victims, suspects, accused, defendants, expert opinions, material evidence, audio and video recordings and other materials obtained in violation of procedural law [4].

The Presidential Resolution of the Republic of Uzbekistan dated on November 30, 2017, PR5268 "On additional measures to strengthen the guarantees of the rights and freedoms of citizens in the judicial proceedings" was another important step in further improving the work in this area. This decree stipulates that the use of information collected in serious violation of procedural law or the use of illegal methods as evidence in criminal cases is not allowed.

The lawyer has given the right to resolve disputes before the court, to take measures to make agreement between sides, as well as to work as the judge of arbitrator court according to the Resolution of the President of the Republic of Uzbekistan dated on May 12, 2018, No PR-5441 "On measures to radically improve the efficiency of the Advocacy institution and expand the independence of lawyers". The period of compulsory internship in the advocacy system has been reduced from six to three months in order to obtain a license to practice law, with the exception of employees of legal services of state bodies and organizations and persons who have worked as judges, investigators or prosecutors for at least three years.

The conception of improving the criminal and criminal procedural legislation of the Republic of Uzbekistan was approved in accordance with the Resolution of the President of the Republic of Uzbekistan dated on May 14, 2018 No PR-3723 “On measures to radically improve 
the system of criminal and criminal procedural legislation".

The objectives like unifying the norms of criminal law; improving the system of criminal liability and punishment; ensuring effective and reliable protection of the rights and freedoms of citizens, the interests of society and the state; systematization and harmonization of norms of criminal procedural legislation; improving mechanisms to ensure reliable guarantees of the rights and freedoms of the individual in the criminal proceedings; as well as the issues such as the introduction of new forms and procedures of criminal procedure have been identified as the main directions and objectives of improving the criminal and criminal procedural legislation of the Republic of Uzbekistan in this resolution.

According to the Decree of the President of the Republic of Uzbekistan dated on December 13, 2019 No PD-4551 "On additional measures to ensure the rule of law and the constitution, strengthening public control and raising the legal culture in society"[5] the procedure for explaining procedural rights and forcibly videotaping attempts to waive defense counsel was introduced from April 1, 2020. Law enforcement officials are obliged to immediately notify one of their family members, or in case of their absence, other relatives or next of kin, of the arrest and whereabouts of the person after their arrest.

According to the Presidential Resolution of the Republic of Uzbekistan dated on August 10, 2020, No. PR-6041 "On measures to further strengthen the guarantees of protection of the rights and freedoms of the individual in the judicial proceedings"[6] it is prohibited to summon or interrogate the defendant, victim, witness, civil plaintiff, civil defendant and other participants in the proceedings to law enforcement bodies as part of the criminal case sent to the court for review by the staff of the interrogation and preliminary investigation organs, as well as taking any written or oral testimony from him/her until the procedural rights of the suspect or accused have been explained to him/her; summoning and questioning law enforcement agencies in the absence of grounds for involving close relatives of the detained suspect or accused as participants in the proceedings; incitement of a person to commit illegal acts by the staff of the pre-trial investigation, inquiry and preliminary investigation organs and accusation of crime committed as a result of such incitement; interrogation of a person as the witness in cases when there are grounds to involve him as a suspect or accused in the criminal case.

New phase of judicial reform serves to protect human rights and legitimate interests in society, as well as eliminates the legal gaps in the law, the implementation of international human rights standards in law and law enforcement, as a result enables effective protection of human rights, freedoms and legitimate interests in our country.

\section{REFERENCES}

1. The Application of the President of the Republic of Uzbekistan, Shavkat Mirziyoyev, to the Oliy Majlis dated on January 24, 2020http://uza.uz/oz/politics/zbekistonrespublikasi-prezidenti-shavkatmirziyeevning-oliy-25-01-2020

2. Resolution of the President of the Republic of Uzbekistan. On measures for further reform of judicial system, strengthening of guarantees of reliable protection of the rights and freedoms of citizens. October 21, 2016. PR-4850. http://www.Lex.uz.

3. Mirazov D. M. Control over preliminary investigation: historical, organizational 
and procedural peculiarities:

monography. Under the general editorship of doctor of science in law, professor, B. Kh. Pulatov. Tashkent: Academy of the MIA, 2015. P. 149.

4. Report on the activities of the Authorized Person of the Oliy Majlis of the Republic of Uzbekistan for Human Rights (Ombudsman) in 2019. - http: ombudsman.uz.

5. Decree of the President of the Republic of Uzbekistan. "On additional measures to ensure the rule of law and the constitution, strengthening public control and raising the legal culture in society". December 13, 2019 No PD4551. - http://www.Lex.uz.

6. Resolution of the President of the Republic of Uzbekistan. On measures to further strengthen the guarantees of protection of the rights and freedoms of the individual in the judicial proceedings. August 10, 2020, No. PR-604. - http://www.Lex.uz. 